\title{
Animals and Animals
}

\author{
Laurence Thomas \\ Professor of Philosophy \& \\ Professor of Political Science in the Maxwell School \\ Syracuse University \\ Ithomas@maxwell.syr.edu
}

\begin{abstract}
Speciesism is the wrong of not acknowledging the moral qualities that non-human animals possess that are similar or equivalent or even superior to the moral qualities that human beings possess. However, since it is manifestly clear that no one thinks that apes are in any way obligated to human beings, it clearly cannot be a form of speciesism to be mindful of the differences on the basis of which that is so. In opposition to the advocates of the Great Ape Project, my aim in this essay is to establish the quite minimal claim that apes should not have the same moral status as human beings because human beings have a far greater capacity for moral responsibility than do apes. The claim that I wish to establish is quite compatible with the claim that apes should be treated in a much more morally wholesome manner.
\end{abstract}

\section{Introduction}

In George Orwell's classic novel Animal Farm, we find the following riveting statement: "All animals are equal but some are more equal than others". It will be recalled that after a most valiant attempt to install complete equality among the pigs on the farm, it turned out that a hierarchy manifested itself among them after all. The point of the story, of course, is that human beings will invariably make distinctions between themselves, even if those distinctions have no basis in hard cold facts. Some maintain that a like claim holds for the moral differences that human beings draw between themselves and all other non-human animals, especially apes. More precisely, they hold that there is no substantive moral difference between the ape and human beings. The numerous individuals who advanced this claim include Jane Goodall, Francine Patterson \& Wendy Gordon, and Peter Singer. In general, this is the core idea of the Great Ape Project and the articles presented in the collection of essays by Paola Cavalieri and Peter Singer entitled The Great Ape Project: Equality 
Beyond Humanity. ${ }^{1}$ And it should no doubt be noted that in 2008 Spain passed legislation according apes the right to life and freedom. I shall return to this point momentarily.

Just what all the supporters of the Great Ape Project mean is perhaps open to debate. However, in their essay "The Case for the Personhood of Gorillas," France Patterson and Wendy Gordon explicitly argue that there is no moral difference between human beings and gorillas or apes. And in their essay "Chimpanzee's Use of Language," Fouts and Fouts insist that there is no substantive difference between the use of language by chimpanzees and the use of language by humans. Indeed, Fouts and Fouts conclude their essay by claiming that chimpanzees are in effect none other than the siblings of human beings. While different authors make different claims, the overall spirit of the essays is that it is rather arbitrary and indefensible to claim that there is any substantive difference between apes and human beings. Such is the general direction of the essays in the volume.

In this essay, I shall that for all the extraordinary parallels that exist between apes and human beings, there is one significant moral respect in which apes and human beings are not moral equal; and that is with respect to moral responsibility. As we all know, a wealth of remarkable parallels is compatible with there being single difference that makes a most significant difference. No decent person thinks that animals should be treated cruelly. And apes are owed a measure of moral consideration that goes well beyond not treating them cruelly. Just so, there is fundamental difference between the level of moral responsibility of which human beings are capable and the level of moral responsibility of which apes are capable, where it is to human beings that the substantially greater capacity for moral responsibility is rightly attributed. So while there are undoubtedly countless changes that human beings should make in the way that they treat apes, it is a mistake to attribute to apes the same capacity for moral responsibility that is properly attributed to human beings. There is, then, a substantive moral threshold between apes and 
human beings rooted in the evolutionary development and biological reality of the two species.

Richard Dawkins rightly notes, in his essay "Gaps in the Mind" (p. 87) that this threshold is but the result of an evolutionary accident; and he is equally right that we should be prepared to change if the line moves. But even an accidental outcome in evolutionary development-and in some sense all such outcomes are accidentalcan have indisputable moral significance if it stays in place for a substantial period of time. The asymmetry between apes and human beings with respect to moral responsibility, where the capacity of human beings surpasses that of apes by far, has shown no signs at all of shifting.

In this regard, let me note here that Spain's own law according apes the right to life and freedom nonetheless accords with there being a significant difference in moral responsibility between apes and human beings; for it is still permissible to keep apes in zoos although a dramatic change in the quality of the zoo environment is now required. Needless to say, keeping human beings in zoos is simply not a moral option under any description. This is inextricably tied to the reality that the capacity moral responsibility is attributed nowadays to all human beings. Throughout history the primary basis for one group of human beings depriving another group of human beings of liberty, where no antecedent wrongdoing is first attributed to the group being thus deprived, is that those being deprived have a substantially diminished capacity for moral responsibility. Notice that whereas Jews were thought to be irredeemably evil and so Jews were murdered who had not committed a single wrongful act, blacks were deemed to be mere moral simpletons who should be enslaved (see Thomas 1993; Thomas 2005).

Significantly, the argument concerning responsibility is entirely consistent with the view that chimpanzees have a right to life. For, as the case of children and the elderly who are afflicted with significant mental deterioration makes manifestly clear, having a right to life 
does not in the least entail that one is capable of any moral responsibility, let alone full moral responsibility.

I begin with some basic reflections regarding human moral responsibility.

\section{Moral Responsibility}

We have a morally significant difference between two creatures, $A$ and $B$, just in case the failure to perform a substantial moral act leaves one creature open to serious moral criticism but not at all the other. By this criterion, we have a morally significant difference between 7-year old human beings and 30-year old human beings, where both are completely healthy. No one expects a 7-year old to make an effort to save the life of an adult who has a massive heart attack in the presence of the child. No one thinks for a moment such a child is open to moral criticism for not doing anything to obtain assistance for the person. Obviously, just the opposite holds if someone should have a massive heart attack in the presence of a 30year old. At the very least, we think that the 30-year old should make a most concerted effort to get some assistance for the heart attack victim. If, instead, the 30-year old decided to take a walk in order to enjoy the evening's cool breeze, this would be deemed as none other than unbridled moral callousness. By contrast, the 7-year old could decide to go out and play without being so charged. If the heartattack victim should die while the 30-year old is taking a walk, then we rightly say that the 30-year old bears some blame for the victim's death. But not in the case of the 7-year old who goes out to play.

More generally, one fundamental difference between the 7-year old and the 30-year old can be put in terms of moral responsibility. A entirely healthy 30-year old can be held morally responsible for (for doing and refraining from doing) a myriad of things for which no healthy 7-year old can be held morally responsible.

So imagine a genetic abnormality, call it the time-warped development affliction, that allows for perfect development in human 
beings up until the age of 7 and then all psychological development stops, though physical development continues. Thus, a person who has the TWD affliction could live for 80 years and have the body of an 80-year old; yet, the person would still have the psychological capacities of only a 7-year old and would behave accordingly. TWD affliction is exceedingly rare. Only one out of every 500,000 infants born are afflicted it.

Now, it would be manifestly wrong to hold that human beings afflicted with TWD are just as capable of moral responsibility as any perfectly healthy human being is. This brings out the quite important truth that, strictly speaking, moral responsibility is not tied to being a member of a certain species; rather, such responsibility is ineluctably tied to having certain capacities.

What is true, of course, is that different capacities are characteristic of each and every species. This is exactly what it means to be a member of one species and not another. Thus, given normal development any member of a given species will have or come to have those capacities should that species-member continue living. This holds no more or less for lions or apes or birds, and so on, than it does for human beings. The simple truth of the matter is that, by far, the overwhelming majority of human beings who reach the age of 30 have the capacities which enable moral responsibility to apply to them. The human species would be a very different species, indeed, were that not the case. In fact, criticizing human beings for not taking apes more seriously morally would itself be rather ludicrous if human psychological development completely stopped at the age of 7 .

By contrast, it is clear that the normal course of the development of animals does not carry in its wake moral responsibility on their part. But what about the case of apes? To this I now turn.

\section{The Ape}

Without a doubt, the resemblance between apes and human beings is absolutely striking. To the most casual observer, it is 
impossible to miss the fact that both apes and human beings are quintessential social creatures, as the work of Jane Goodall (1971, 1996) makes abundantly clear. An ape left in complete isolation would become psychologically deranged just as a human being would. Apes form bonds of affection in ways that are analogous to the formation of such bonds among human beings. Thus, just as a human being can miss a loved-one, it is clear that apes can, too. And just as many human skills, of which speaking is perhaps the most obvious, are acquired through social interaction, the same holds for ape. What is more, apes clearly take delight in engaging in mimicking, mocking, and teasing behavior in just the way that humans do. Apes engage in such behavior with one another; they engage in such behavior with human beings. No doubt the piece de resistance with regard to putting apes on the same moral plane as human beings is that apes can be taught a language, it being understood that being able to learn a language is on an entirely different and vastly higher plane than being able to parrots various words. No other non-human living creature comes even close to having this capacity (see Roger S. Fouts and Deborah H., Fouts, "Chimpanzees' Use of Sign Language"). I shall return to this point in Section $\S 3$ below.

The proponents of the Great Ape Project thus conclude that when these considerations are given the weight that they should be given, it would seem that there can be no justification for failing to conclude that that apes should have the same moral standing that human beings have (see Patterson and Gordon, "The Case for the Personhood of Gorillas").

Now, although I am not interested in quibbling, I do wonder whether this move to assert parity between the psychological development of apes and human beings is a bit too quick. For instance, is it being claimed that apes at the very height of their developmental powers exactly on a par with human beings at the height of their developmental powers-such as a 30-year old? Or, do we have something more akin to the following: apes at the height of 
their developmental powers are rather like human beings in fullbloom at the age of, say, 7-years old. 7-year old human beings can be a lot of fun and they can do lots and lots of creative things. Healthy 7year old children are full of surprises. But, as I have indicated in Section $\S 1$, it is an incontrovertible fact that no one would ever suppose that a 7-year old human being is equal in psychological development to a 30-year old human being. So, it makes an enormous difference whether the claim is that apes are more like a completely healthy 7-year old or they are more like a completely healthy 30-year old. There is simply no evidence whatsoever that the latter is the case. To be equivocal here is disingenuous at best and morally wrong at worse. One can easily raise the human age to 10 or 12. There is still an absolutely phenomenal difference in terms of moral responsibility between a 30-year old and a 12-year old.

If there were no difference at all in the psychological development of a fully developed ape and fully developed 30-year old person, then moral responsibility would apply equally to both of them.

Perhaps nothing brings out more the importance of clarity here than the real-life instance in 2009 of the ape of Sandy Herald, named Travis, who mauled the face of Charla Nash, who was visiting the home of her friend Ms. Herald. If Travis is rather like a 30-year old human being, then Travis is either deranged or evil. If, by contrast, Travis is rather like a 7-year old, then we have a different assessment entirely. In order to rescue Nash, the police eventually had to shoot Travis. Suppose, though, that they had been able to save Nash without killing Travis. What is unequivocally clear is that the very idea of holding Travis morally blameworthy for his behavior would have been simply out of the question. It is irrelevant that Travis may have been given xanax, since surely that is not reason why he is not held morally blameworthy for his behavior. And while the very idea of having Travis as a pet is undoubtedly fulsome to those who advocate for the equality of apes, it is worth noting that Ms. Herald 
treated Travis more like a friend than a pet. Reportedly, they took baths together, he regularly combed her hair, and they shared a bed.

In any event, the point remains that the idea of morally blaming Travis, and so holding him morally responsible, for his behavior simply does not get off the ground. And the reason for this stems not so much from the thought that he should never have been living among human beings in the first place as it does from the reality that holding a ape blameworthy is essentially incoherent. Notice that we would make the exact same assessment had Travis traversed a forest and seized upon and killed a human being walking along the edge of a creek because Travis deemed that his terrain was being violated.

The concluding example of the preceding paragraph brings us to another matter that needs to be noted regarding the ability of apes to exhibit behavior that mirrors human behavior.

Understandably, much is made of the idea that apes can learn a language. What no one draws attention to, however, is just how limited this is. In this regard, the difference between the speaking capacity of a 7-year old human being and a 30 old human being is most illuminating. If a 7-year old had the command of a language equivalent to that of a 30-year old that would be impressive beyond measure. The child would clearly be gifted. There is absolutely no evidence whatsoever that an ape's command of a language could ever be equal to the command that a 30-year old has of that language. This proves to be significant because, with human beings, there is a positive correlation between language development and the development of moral capacities. No one, for instance, expects a 7year old to grasp the significance of trust anywhere near the extent to which a 30-year old does. Indeed, in terms of tonality, bodily language, and word-choice, the way in which we would speak to a 7year old who violated our trust should be fundamentally different than the way in which we would speak to a 30-year old who has done so. To state the obvious, the very idea that one should trust a 7-year old in precisely the same manner and to the same extent that one would trust a 30-year old is an entirely indefensible stance. 
At the age of 30, words can (and so often do) have a moral gravitas that has no equal whatsoever in the life of a child at the age of 7 or even 12. So it is whether we are talking about moral or immoral behavior. Thus, to take the case of immoral behavior, the utterance of a sexist or racial slur by a 7-year old is one thing; whereas it is quite another when uttered by a 30-year old. Is it being claimed that words can attain this level of moral weightiness in the lives apes?

A related point has to do with self-concept. Suffice it to say that there is also a direct correction between language development and the development of a self-concept. Every 30-year old can think of a multitude of ways in which the self-concept of a 7-year does not approximate the self-concept of a 30-year old. This point most certainly holds between apes and 30-year olds. Sexuality and talent are quite salient examples in this regard. As I noted above, it was reported that Ms. Herald would often take baths with Travis. What one simply does not imagine is that the ape Travis ever had the following thought whilst they were in the bathtub together: "Nice, this might lead to something more interesting. What has taken her so long? I have much more going for me in terms of personality than her deceased husband. I deserve it”.

The preceding observations are quite searching because they forcefully raise the question of what exactly the proponents of the Human Ape Project mean when they insist that apes and human beings should be deemed equal in their moral status. For surely the argument cannot be that apes see themselves as deserving of the same moral status that human beings have. This, to be sure, does not entail that apes should not have that status. If, however, the very nature of apes is such that they lack the psychological wherewithal to see themselves as deserving of the same moral status as human beings (a point to which I return in the section below), then it looks for all the world as if we have a quite significant moral difference between the two species. This, in turn, would suggest that if apes should have the same moral status as human beings, it cannot be for 
exactly the same reasons that human beings have moral status they have that apes should also have that moral status.

\section{Reflections from Darwin}

In the Descent of Man, Charles Darwin makes the following observation: ". . . the difference in mind between man and the higher animals [for example, apes], great as it is, certainly is one of degree and not of kind" (Darwin 1874, Chpt. IV under "Summary of the last two chapters"). The observation is clearly a double-edge sword. On the one hand, the point is that human reasoning is not so different from the reasoning of the higher animals that human beings should conclude there are no similarities in the reasoning that takes place between the two groups. On the other, he concedes that the difference in terms of powers of reasoning is considerable. Darwin's remark is compatible with the view that it is mistake for human beings to think that reasoning on the part of human beings is so different from reasoning on the part of higher animals that the former cannot learn anything from observing the latter. Yet, this observation stops considerably short of entailing that human beings and the higher animals should be accorded the same moral status. Indeed, Darwin is clear that there are substantial differences between human beings and the higher animals in terms of the concepts that the former (but not the latter) grasp; and he held that in many instances the development of these concepts is tied to the use of language. He observed that as of the writing of his essay, The Descent of Man, the precept known as the Golden Rule is held only among human beings. What Darwin denied is that these differences are fixed in perpetuity-a quite modest claim for an evolutionary theorist. As the arguments of Patrick Blandin (2007) remind us, the malleability of living things would seem to have a plausibility that not even Darwin himself imagined.

What makes language so important? The answer, I believe, following Thomas Nagel's idea in The Possibility of Altruism, is that language makes it possible for creatures to indicate publicly and explicitly that they simultaneously take both their future selves 
seriously and the selves of others equally seriously. This verbal affirmation that human beings can give to one another, which often takes the form of promise-making, is of extraordinary significance (see Grice 1989). Marriage vows, which are a form promise-making, are surely the quintessential example of this simultaneity. This is perhaps part of the reason why witnessing these vows is so very moving although we already know the words and, in some instances, have heard them on many occasions. For there is no equal to witnessing that moment of the public simultaneous affirmation of the "self" and the "other" unfold. Language, of course, is not the only way in which human beings can affirm themselves and one another. Just so, nothing whatsoever replaces the public affirmation of both that comes with language. What we all know is that no matter how intently and movingly two human beings look at one another face-toface, the utterance of the words "I love you" makes an utterly nontrivial difference.

For these and countless other reasons, I locate the difference between apes and human beings at the level of responsibility. The level of responsibility that we accord to fully-developed adult human beings far exceeds the level of responsibility that we accord to fullydeveloped adult apes. This difference in responsibility is supported by Darwin's observation that human beings constitute the only species where the observance of the Golden Rule takes place among its members among its members.

Arguably, there is a conceptual overlap between the members of a species being such that they come to speak a natural language in the course of their normal biological development and the members of that species having a quite substantial capacity for moral responsibility. Indeed, one reason why we know that the slaveowners of American Slavery were more than a little disingenuous in their assessment of black slaves is that the slaveowners routinely had their children cared for and succored by black slaves, with all that this entailed in terms of verbal communication and affirmation. It would never have occurred to the slave owners to have their children cared 
for by dogs or deer or even apes. And for all the talk by the authors in the anthology The Great Ape Project about the moral personhood of apes, surely no one would dare suggest that it makes no morally relevant difference whether we have a human being or an ape be the primary care taker of a human infant. The problem is not so much that the apes would intentionally harm the infant human being, but that in terms of moral development what we would have is a human being who is rather like someone who is afflicted with the fanciful case of Time Warped Development affliction described in Section §1 above (see Baertschi 1995).

I have drawn attention to American Slavery precisely because it is not uncommon for those to argue for the rights of apes to draw a comparison to the mistreatment of apes and the wrong of human slavery generally, as Cavalieri and Singer vividly do in their epilogue "The Great Ape Project - And Beyond". For the reason just mentioned, slaveowners were clearly in denial regarding the equal humanity of black slaves. I agree without hesitation that human beings have been in denial regarding the remarkable moral capacities that apes possess. My only point is that the moral capacities possessed by apes surely do not give us moral parity between apes and human beings. For then there would be no difference between the responsibilities of apes to human beings and the moral responsibilities of human beings to apes. Notice, too, that the very idea of applying legal responsibility to apes is all the more indefensible. Yet, the end of slavery for human beings has properly meant according human beings full legal standing and so the responsibility thereunto appertaining, it being understood that legal responsibility presupposes the capacity for moral responsibility.

It is arguable that some human beings have failed to see themselves as morally equal to other human beings. Presumably, the oppression of slavery can have that effect upon many of its victims. So there is a very real sense in which these oppressed individuals needed someone to speak on their behalf. For when these slaves and, in particular, the children of these slaves were treated as moral 
equals, they fully grasped this moral reality and it properly resonated with their humanity. That is what we would expect. This stands as a sort of resounding proof that the charge of inherent inferiority with respect to this or that group was ever so mistaken.

It would be a mistake, however, to think that the case of apes is exactly analogous to slaves thus oppressed. No defender of the moral equality of apes has even come close to suggesting that a like moral awakening would happen to apes if only human beings were to treat apes as moral equals. And this suggests the mistreatment of apes and the enslavement of human beings, though both clearly and unequivocally wrong, are not the moral parallel that so many defenders of the Great Apes Project claim it to be.

\section{Animals and Human Beings: Some Concluding Remarks}

The slogan of the Great Apes Project is "Morality Beyond Humanity". The meaning is clear, namely that morality applies equally and fully to creatures other than human beings. Ironically, the moral reality of things undermines the very symmetry that is being put forward as a moral ideal. For no one argues that nonhuman animals have a moral responsibility to one another. Nor, a fortiori, does anyone argue that non-human animals have a moral responsibility to human beings. It is no accident that the moral responsibility for moral equality tout court is entirely one directional, namely from human beings to animals. After all, if moral equality so applies, the ineluctable fact of the matter is that it is only human beings who have the capacity to take on the moral responsibility of so upholding such a conception of morality. Indeed, it is only human beings who can give articulation to that very ideal, and so who can thus publicly affirm the equal moral standing of all. It would be an entirely different world if apes could look human beings in the eyes and exclaim "We apes should take you human beings as morally seriously as we apes take one another". That, alas, is simply not a possibility-at least not at this point in the evolutionary development of living things. 
Presently, it is woefully implausible to hold that apes can take one another as seriously as moral creatures as human beings can take one another. This is what makes the marriage example given above so significant. A fortiori, then, it is implausible to suppose that apes can take human beings seriously enough as moral creatures to come close to being owed the moral considerateness that human beings rightly owe one another.

Needless to say, the view that human beings owe animals, especially apes, a level of moral considerateness that heretofore they have not accorded animals is most defensible. In fact there may be some truth to Schopenhauer's suggestion, in his essay On the Basis of Morality, that being morally considerate to animals makes human beings morally better creatures. But that truth does not require putting animals, especially apes, and human beings on the same moral plane. This is demonstrated by the argument of Section $\S 1$.

If there were such an abnormality as time-warped development affliction, it is manifestly clear that any 30-year old human being with the TWD affliction should be treated with considerable compassion and decency. Indeed, Schopenhauer's observation would seem ever so applicable here. However, the asymmetry is also manifestly clear: Precisely because of the significant different in capacities between healthy human beings and TWD afflicted human beings, the considerateness would be an asymmetrical one of moral responsibility on the part of healthy human beings towards TWD afflicted human beings. By hypothesis, TWD afflicted human beings are human beings who suffer from an abnormality. What is true, alas, is that not owing to any abnormality at all apes do not equal the moral and intellectual capacities of healthy human beings. Hence, while it is certainly plausible to hold that apes are owed a level of moral considerateness heretofore denied to them, it is not at all plausible to argue that this so is because apes and human beings are on the same moral plane.

If the idea of morality beyond humanity that has been put forward by the Great Ape Project means that apes are owed a level of 
moral considerateness heretofore denied to them, then we a claim that is quite tenable. If, however, the claim is that apes are owed precisely the same level of moral considerateness that human beings are owed because there is no morally relevant difference between apes and human beings, then what we have is an untenable claim. For if we have a morally relevant difference between human beings afflicted with TWD and those who are not, then surely we have a morally relevant difference between apes and human beings. It is simply not possible that we could have a morally relevant difference in the first instance but not the second one.

Speciesism is the wrong of not acknowledging the moral qualities that non-human animals possess that are similar or equivalent or even superior to the moral qualities that human beings possess. However, since it is manifestly clear that no one thinks that apes are in any way obligated to human beings, it clearly cannot be a form of speciesism to be mindful of the differences on the basis of which that is so. In this essay, I have aimed for no more but then also no less than precisely that ${ }^{2}$.

\section{Notes}

1. (New York: St. Martin's Griffin 1993). Unless a year is given after a name, references are essays contained in the collection of essays by Cavelieri and Singer.

2. A profound note of thanks goes to the students of Philosophy 191, with whom over the past three semesters I have discussed the idea of equality between apes and human beings as we read various essays in Paola Cavalieri and Peter Singer (eds.). The penultimate version of this essay was commented upon by Adam Schechter and Joseph Lynch, I am so very grateful to them both for their searching comments that have given rise to significant improvements in this essay.

\section{References}

Baertsci, Bénard. 1995. La valeur de la vie humaine et l'intégrité de la personne. Paris : Presses Universitaires de France. 
Blandin, Patrick. 2007. Biodiversité: L’avenir du vivant. Paris: Éditions Albin Michel.

Calvieri, Paola and Peter Singer, eds. 1993. The great ape project: Equality beyond humanity. New York: St. Martin's Griffin.

Darwin, C.1874. The descent of man. The Project Gutenberg Etext, http://www.gutenberg.org/cache/epub/2300/pg2300.html, accessed 9/27/2010 9:44pm PST.

Fisher, John Martin and Mark Ravizza, eds. 1993. Perspectives on moral responsibility. Ithaca, NY: Cornell University Press.

Goodall, Jane. 1996. My life with champanzees. New York, NY: Aladdin Paperbacks.

. In the shadow of man (revised edition). New York, NY: Mariner Books.

Grice, Paul. 1989. Studies in the way of words. Cambridge, MA: Harvard University Press.

Nagel, Thomas. 1979. The possibility of altruism. Princeton, NJ: Princeton University Press.

Thomas, Laurence. 1993. Vessels of evil: American slavery and the Holocaust. Philadelphia, PA: Temple University Press.

Thomas, Laurence. 2005. Moral equality and natural inferiority. The J ournal of Social Philosophy 31 (2005). 